\title{
Evaluating the Floral and Avian Communities of an Ohio Wetland at The Wilds: 7 Years After Restoration
}

RILEY JONES ', Department of Restoration Ecology, The Wilds, Cumberland, OH, and Department of Biology, Denison University, Granville, OH, USA; REBECCA SWAB, Mad Scientist Associates LLC, Westerville, OH, USA; STEPHEN SPEAR, Department of Wildlife Ecology, The Wilds, Cumberland, OH, USA.

ABSTRACT.Wetland restorations have become an important tool in ecosystem management and have contributed to stabilizing hydrology and nutrient cycles, increasing native plant cover, and improving water quality. Longterm monitoring is essential for evaluating the success of a wetland restoration. However, wetland restorations are often monitored for short time periods compared to the timescale on which some abiotic factors change. Vegetative and avian assessments were conducted for a partially restored wetland on a reclaimed mine site, located at The Wilds ${ }^{\circledR}$ in Cumberland, Ohio. These assessments were performed from June through August 2018, 7 years after the initial restoration, using the unrestored portion as a comparison to evaluate restoration effectiveness. The restored wetland is characterized by open water with emergent vegetation, whereas the unrestored portion is largely a dense cattail (Typhus spp.) stand with low levels of standing water. The vegetative surveys used the Ohio EPA's Vegetation Index of Biotic Integrity for Emergent Vegetation (VIBI-E) and the bird surveys used a modified point count method. VIBI-E data are available for the study wetland from 1 year before restoration until summer 2018, while the avian study represents the first bird point count survey in the 2 wetland categories. The year 7 VIBI-E score of the restored section was the highest it has been since the restoration occurred and indicated "good" quality based on Ohio EPA scoring. The year 7 VIBI-E of the unrestored section has not changed since monitoring started and indicated "restorable" quality. The bird surveys showed higher richness associated with the restored wetland areas. These results demonstrate both the ecological value of wetland restoration and the ability for wetland restoration to maintain the ecological benefits over several years.

\section{INTRODUCTION}

Wetlands are vital areas of biodiversity, housing disproportionately large amounts of endangered species due to the vast destruction of these habitats (Williams and Dodd 1978; Cronk and Fennessy 2001; Zedler and Kercher 2005). Approximately 49 million hectares (122 million acres), or $55 \%$, of the original wetlands in the United States have been destroyed by urban and agricultural development since Europeans arrived (LePage 2011). Wetland destruction has been more extreme in Ohio, where only $10 \%$ of the original wetlands remain (Mitsch and Day 2006). Historically, wetlands were generally thought of negatively by the public as obstructions to development. But public perception started to change in the late 1970s (Kusler and Kentula 1990; Dahl 2006; LePage 2011). This change in public perception is due to the realization of the many services wetlands provide; 4 of the most significant of these services are water quality improvement,

${ }^{1}$ Address correspondence to Riley Jones, Department of Biology, Denison University, Granville, OH 43023, USA. Email: jones_r2@denison.edu biodiversity support, flood mitigation, and nutrient and carbon management (Kusler and Kentula 1990; Zedler and Kercher 2005). Since the mid-2000s, US wetland restoration and creation efforts have surpassed US wetland destruction, leading to an annual net gain of approximately 13,000 hectares (32,000 acres) (Dahl 2006; LePage 2011).

Wetland restoration projects seek to recover degraded wetland functions and services by targeting certain assemblages of flora as well as desirable abiotic characteristics such as appropriate hydrological features and stable nutrient cycles (Moreno-Mateos et al. 2012). While it is currently unknown how long it takes for ecosystems to fully recover after disturbance, current estimates range from several decades to centuries (Jones and Schmitz 2009; Moreno-Mateos et al. 2012; Moreno-Mateos et. al. 2015). However, most restorations are rarely monitored longer than what is required by law,

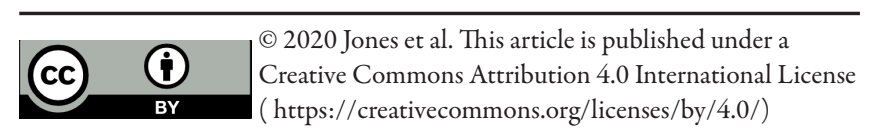


mostly due to the difficulty of obtaining funding to continue long-term monitoring (Ruiz-Jaen and Aide 2005; Robertson et al. 2018). For example, under the Clean Water Act, mitigation sites are required to be monitored for at least 5 years-even though soils affected by mining can take over 15 years to recover to similar values to undisturbed soil (RuizJaen and Aide 2005; CMLAR 2008; Robertson et al. 2018). Vegetation is almost always included in post-restoration monitoring, as recovery of fauna and other ecological functions often follow recovery of vegetation (Ruiz-Jaen and Aide 2005). For example, a correlation has been found between recovery of birds and recovery of diverse vegetation structure (Ruiz-Jaen and Aide 2005).

"The ultimate goal of restoration is to create a selfsupporting ecosystem that is resilient to perturbation without further assistance" (Ruiz-Jaen and Aide 2005). Due to the prevalence of invasive species in degraded ecosystems, however, recolonization is a serious concern. Therefore, tracking potential recolonization of invasives into restored areas is why long-term monitoring of restored sites is vitally important to the success of restoration and mitigation projects. Matthews and Spyreas (2010) found that restored wetlands followed desired trajectories towards high-quality target states for the first 4 years of monitoring, but then deviated from those ideal trajectories and converged upon the vegetative community of degraded wetlandsmainly due to the recolonization of invasive species. Due to wetlands forming in landscape sinks (which then collect nutrients, sediment, seeds, and pollutants from the surrounding land as water flows in), wetlands are extremely vulnerable to invasive plants (Boers et al. 2006). Wetland invasives are categorized by their rapid growth, aquatic seed dispersal, and broad ecological niches (Zedler and Kercher 2004). For example, Typha spp., or cattails, are extreme generalists: their seeds germinate under a wide range of water depths and tolerate a wide range of soils (Kantrud 1986). Invasive species often out-compete more specialized or slower growing plants, leading to a decline in species diversity and establishing monotypic stands (Kantrud 1986; Galatowitsch et al. 1999; Zedler and Kercher 2005; Aronson and Galatowitsch 2008). Monotypic stands are typically less effective at controlling nutrients than diverse communities, and eutrophic conditions can lead to further degradation of the ecosystem
(Boers et al. 2006). Due to the dominating and resilient nature of invasives, restored areas may be recolonized over time, thus creating the need for monitoring and control after the initial project is complete (Kennedy et al. 2002).

Many restoration and mitigation projects aim to provide suitable habitat for breeding wetland bird and waterfowl populations (VanRees-Siewert and Dinsmore 1996; Ortega-Álvarez and LindigCisneros 2012). Birds, due to their relatively high position in trophic webs and sensitivity to pollutants, are a bio-indicator of ecosystem health (Furness 1993; Tsipoura et al. 2008; Zhang and Ma 2011; Ortega-Álvarez and Lindig-Cisneros 2012). Habitat heterogeneity, vegetation, wetland size, and time since restoration each factor into the richness and diversity of bird species present (Kantrud 1986; Gibbs et al. 1991; VanRees-Siewert and Dinsmore 1996; Brown and Smith 1998; Ortega-Álvarez and Lindig-Cisneros 2012). Birds have been found to prefer wetlands with high vegetative heterogeneity over wetlands dominated by tall, monotypic stands (such as those formed by Typha spp.) (Kantrud 1986; Lehikoinen et al. 2017). A review of previous literature has found that 33 to $66 \%$ emergent cover is ideal, as intermediate cover supports a greater species richness than closed $(>66 \%)$ or open $(<33 \%)$ wetlands; additionally, breeding species richness increases with increasing emergent cover (Gibbs et al. 1991; VanRees-Siewert and Dinsmore 1996). Marsh bird use of restored/mitigation wetlands versus natural wetlands is a relatively well studied field, as it is important to determine if the restored wetlands are providing the same habitat quality as an undisturbed wetland (Delphey 1991; Delphey and Dinsmore 1993; Brown and Smith 1998; Brusati et al. 2001; Ratti et al. 2001; Brown 2008; Desrochers et al. 2008). However, the comparison of bird use of restored versus unrestored wetlands has rarely been studied (Seigel et al. 2005). Partially restored wetlands, such as the location of this study, give the unique opportunity to compare avian presence in an unrestored wetland with their presence in an adjacent restored wetland.

Miller Valley Wetland, located at a conservation facility known as The Wilds ${ }^{\circledR}$ in Muskingum County, Ohio, is an example of a restoration project that benefits from repeated monitoring. In 2011, a restoration project-consisting of the installation of a weir and a controlled drainage 
system, along with mechanical and chemical removal of invasive plant species-was completed in 6.5 of the 22 hectares ( 16 of 55 acres) of the wetland. While restoration of all 22 hectares (55 acres) was planned, further restoration has not occurred due to funding constraints. Accordingly, the restored (native-dominated) community is still directly connected to the unrestored (invasivedominated) community due to the stream flowing from the unrestored to the restored section. As plant communities change over time through means of succession, the biological barrier (i.e., the separation of communities due to species composition) between the restored and unrestored habitats may degrade (Kennedy et al. 2002). The goal of this study, therefore, was to continue monitoring the vegetative community in the restored portion of the wetland, while also comparing it to the community of the unrestored portion. As this was an ongoing project, the vegetation data collected in 2018 builds off data from previous years to create a trendline of vegetative community health. In addition, an initial avian community survey was completed as a supplementary tool for future management decisions regarding Miller Valley Wetland. The data collected here will help determine if the goals of the original restoration project (such as greater native and obligate species richness and greater floral diversity) are being met, as well as provide information about succession over time.

\section{Site Description}

The study site is the Miller Valley Wetland, lat 39 $50^{\prime} 42.4^{\prime \prime} \mathrm{N}$, long 81 $42^{\prime} 46.1^{\prime \prime W}(39.8451 \mathrm{~N}$, $-81.7128 \mathrm{~W})$, located on The Wilds, a conservation facility in Cumberland, Ohio, United States. The Wilds is housed on almost 4,000 hectares $(10,000$ acres) of reclaimed surface mining land. The tract that Miller Valley Wetland currently occupies has been subjected to various land uses due to farming and mining activities. In the late 1950s a land bridge was constructed over the wetland valley in order to more easily haul mining materials. In 1982 the valley flooded due to a blocked culvert, creating a 24-hectare (60-acre) sediment lake known as Lake Rise and Fall. (The following timeline was obtained from a 2016 The Wilds internal document detailing the history of Miller Valley Wetland, provided by K. Kirkpatrick; unreferenced.) In 1984 the dam was removed, creating a silted mud flat marsh wetland. Beavers (Castor canadensis) then created and maintained a varied hydrology. In 2006, however, the beavers entirely abandoned the wetland, leading to a dramatic decrease in water level and an increase in invasive plant species. In 2011 approximately 6.5 hectares of the 22-hectare (16 of 55 acres) wetland underwent restoration. Invasive species such as cattails (Typhaspp.) (both narrowleaf and hybrid cattails were present), autumn olive (Elaeagnus umbellata), reed canary grass (Phalaris arundinacea), common reed (Phragmites australis), and others were removed through mechanical and chemical means. Riparian zones were replanted with a highly diverse mix of herbaceous and woody native species, introduced through 13,000 native plant plugs, 3,000 native trees, and approximately $34 \mathrm{~kg}$ (75 pounds) of seed. Finally, a recycled vinyl sheet pile weir was installed to rebuild and control the hydrology. While there has been almost yearly monitoring, only minimal restoration work has been done since the initial restoration (Fig. 1).

\section{Vegetative Surveys}

A permanent $2 \times 5$ grid pattern transect, as described by Peet et al. (1998), was established in 2010 (shortly before the restoration project was complete) in order to evaluate the wetland integrity using the Vegetation Index of Biotic Integrity (VIBI). This original transect, hereafter referred to as T1, is located on the northern edge of the restored section of the wetland, within the emergent boundaries (Fig. 2). The area $\mathrm{T} 1$ has been evaluated using the VIBI method since 2010, completed by various staff members and summer interns of The Wilds. A second VIBI transect (T2), with a similar grid pattern, was established in 2016 in the unrestored portion of Miller Valley Wetland. T2 was also located on the northern edge of the wetland within the emergent boundary. From 28 June to 28 July 2018, a VIBI was performed at each transect following the Ohio EPA standard field method (Mack and Gara 2015). Based on the species and their relative abundances found in the modules, the wetland is assigned a primary and secondary community that describes the dominant types of vegetation-for example, a primary community of cattail marsh. These community designations are used to determine which VIBI category should be used to calculate the score. Biomass samples were 

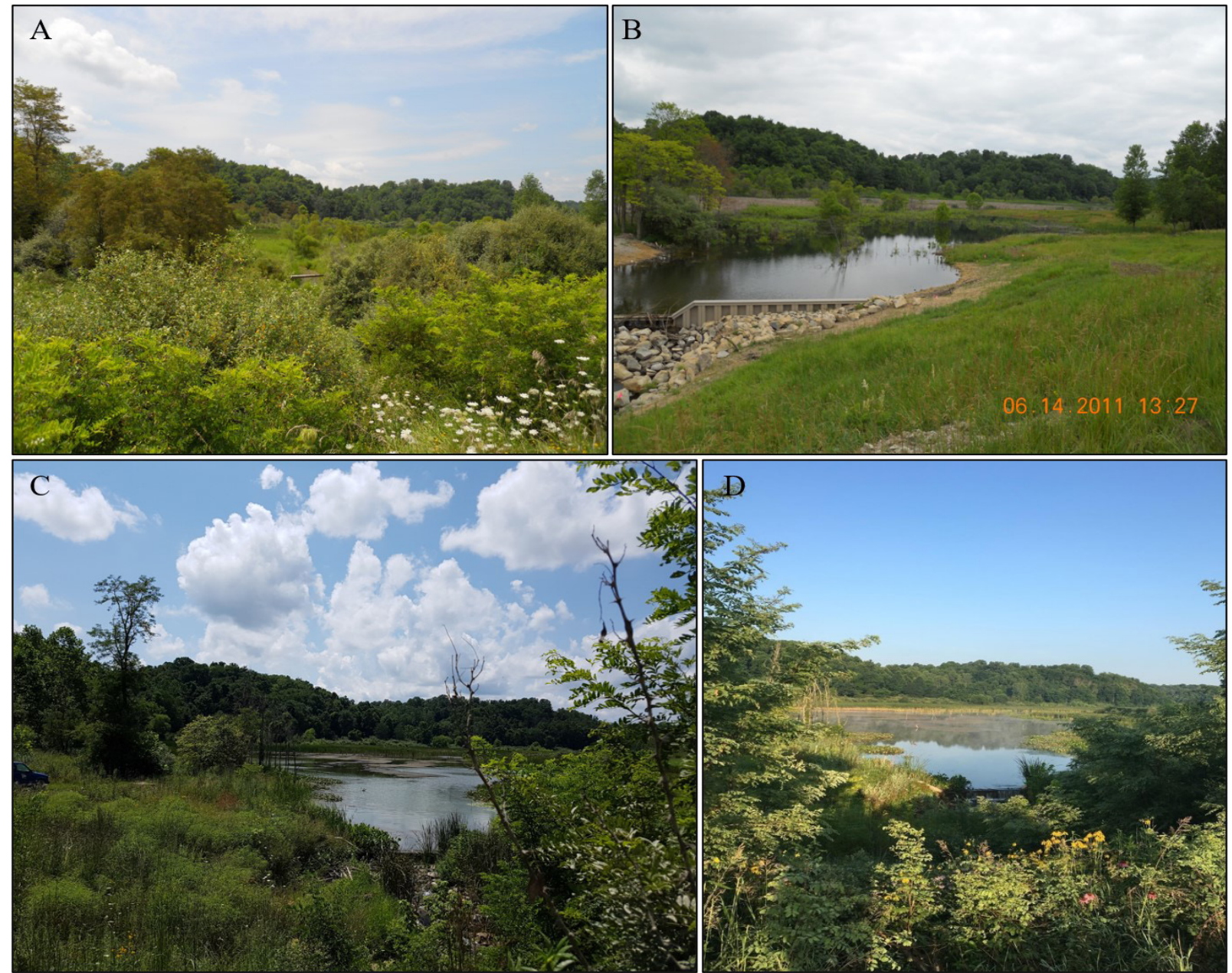

FIGURE 1. Pictures of Miller Valley Wetland (A) before restoration (June 2010), (B) after restoration (June 2011), (C) July 2017, and (D) August 2018. Photo point was located overlooking the weir (lower left in B, bottom center in C and D).

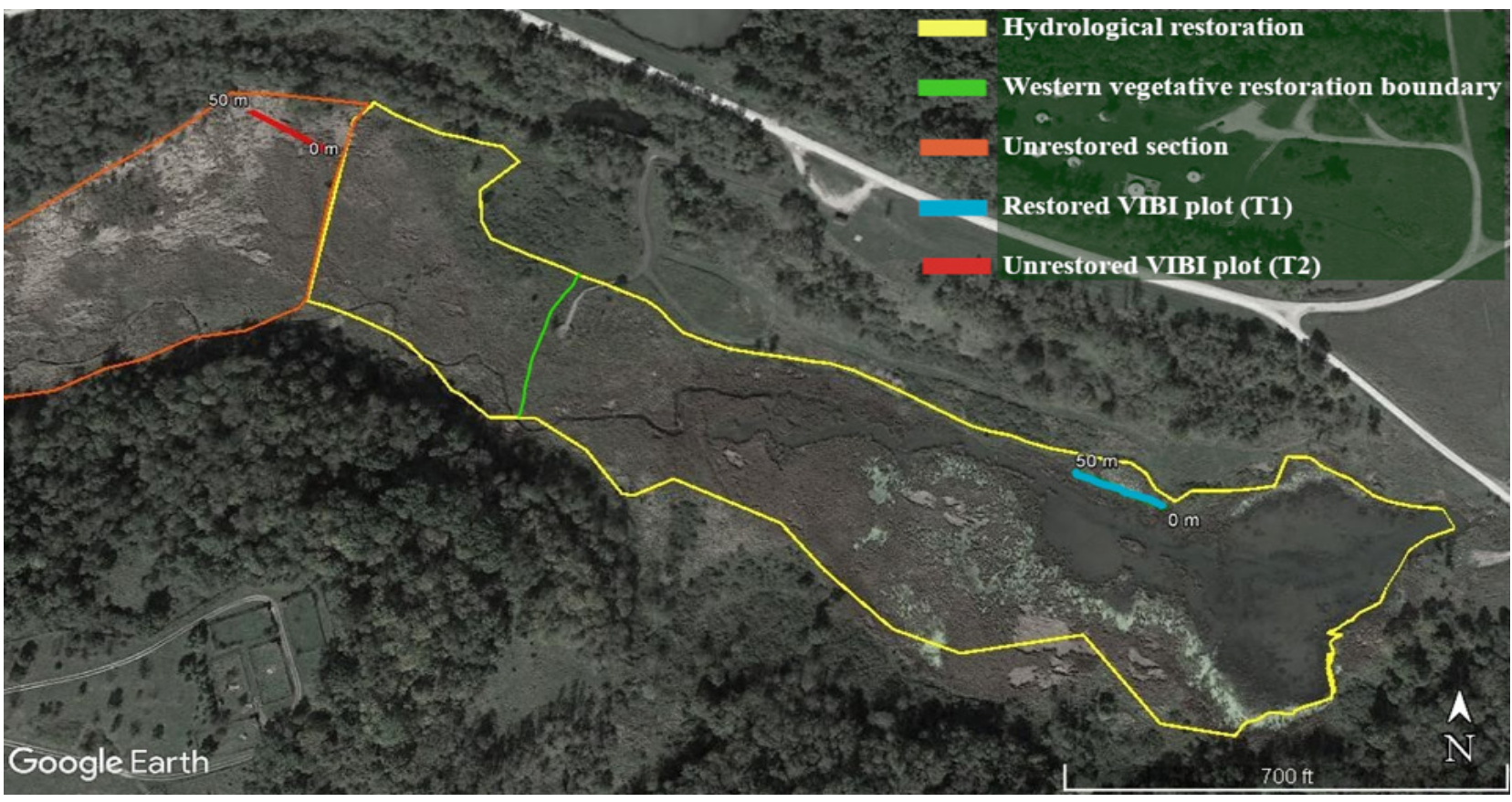

FIGURE 2. Graphic of VIBI transects across Miller Valley Wetland, with restoration project boundaries outlined. The yellow border outlines the hydrological restoration, while the green line marks the western boundary of the vegetative restoration (invasive removal, native planting, etc.). The orange outline represents the unrestored section, which continues west off the image. The blue line marks the restored VIBI plot (T1), and the red line marks the unrestored VIBI plot (T2). Map originally drawn by Katie Kirkpatrick, edited by Riley Jones. 
harvested from 2 opposite corners of each intensive module. Harvesting was accomplished by clipping all rooted vegetation, at dirt level, within a $0.1 \mathrm{~m}^{2}$ quadrat. After recording the wet weight (grams) soon after harvest, biomass samples were air dried for at least 72 hours and then weighed.

VIBI data was analyzed using the Ohio EPA's "Automated Spreadsheets for Calculating and Reporting the Vegetation Index of Biotic Integrity (VIBI) Metrics and Scores v. 2015.2.” Two VIBI categories were used: the VIBI-E, for emergent communities, and the VIBI-FQ for floristic quality. The VIBI-FQ uses only 2 metrics with a maximum of 50 points each: diversity and dominance. Specifics on calculating the Floristic Quality Assessment Index (FQAI) can be found in Andreas et al. (2004). Diversity is calculated by using the FQAI and the following equation:

$$
\left(\frac{F Q A I-10}{20}\right) \times 50
$$

Dominance is calculated by multiplying the relative cover of each species by its coefficient of conservatism (C of C) value (Andreas et al. 2004). The VIBI-FQ is useful to compare wetlands with different hydrogeomorphic (HGM) classes, as traditional VIBIs are influenced by the HGM class of the plot; this allows wetlands that have similar plant assemblages (or are neighboring) to be directly compared in order to see overall trends in a larger area (Spieles et al. 2006; Gara 2016). The VIBI-FQ scoring system is more accurate than the traditional VIBIs (Gara 2016). Additionally, because the FQAI weighs species by assigning higher values to rare and specialist species, it is a useful indicator of the specificity of the plant community (Johnston et al. 2009; Brandt 2013). Vegetation species, cover, and biomass data were put into the automated spreadsheet to calculate VIBI-E and VIBI-FQ scores.

\section{Avian Surveys}

From 8 July to 5 August 2018, 8 total point count bird surveys were conducted at Miller Valley Wetland. The survey followed a modified version of the Standardized North American Marsh Bird Monitoring Protocol that excluded the call broadcast period (Conway 2011). This survey was conducted using survey rounds: each survey was completed within a 10-day window, with each window separated by 7 days. The survey windows were 8 to 17 July and 27 July to 5 August. Surveys were completed both in the morning (starting 30 minutes before sunrise and ending approximately 1 hour after sunrise) and evening (starting approximately 1 hour before sunset and ending 30 minutes after sunset). Six survey points were established along the transect to maximize coverage of the tall emergent marsh habitat (Fig. 3). While the surveys (due to logistical issues) did not extend into the section with no restoration efforts, the 3 western-most points were considered proxies for the unrestored section due to similarity in

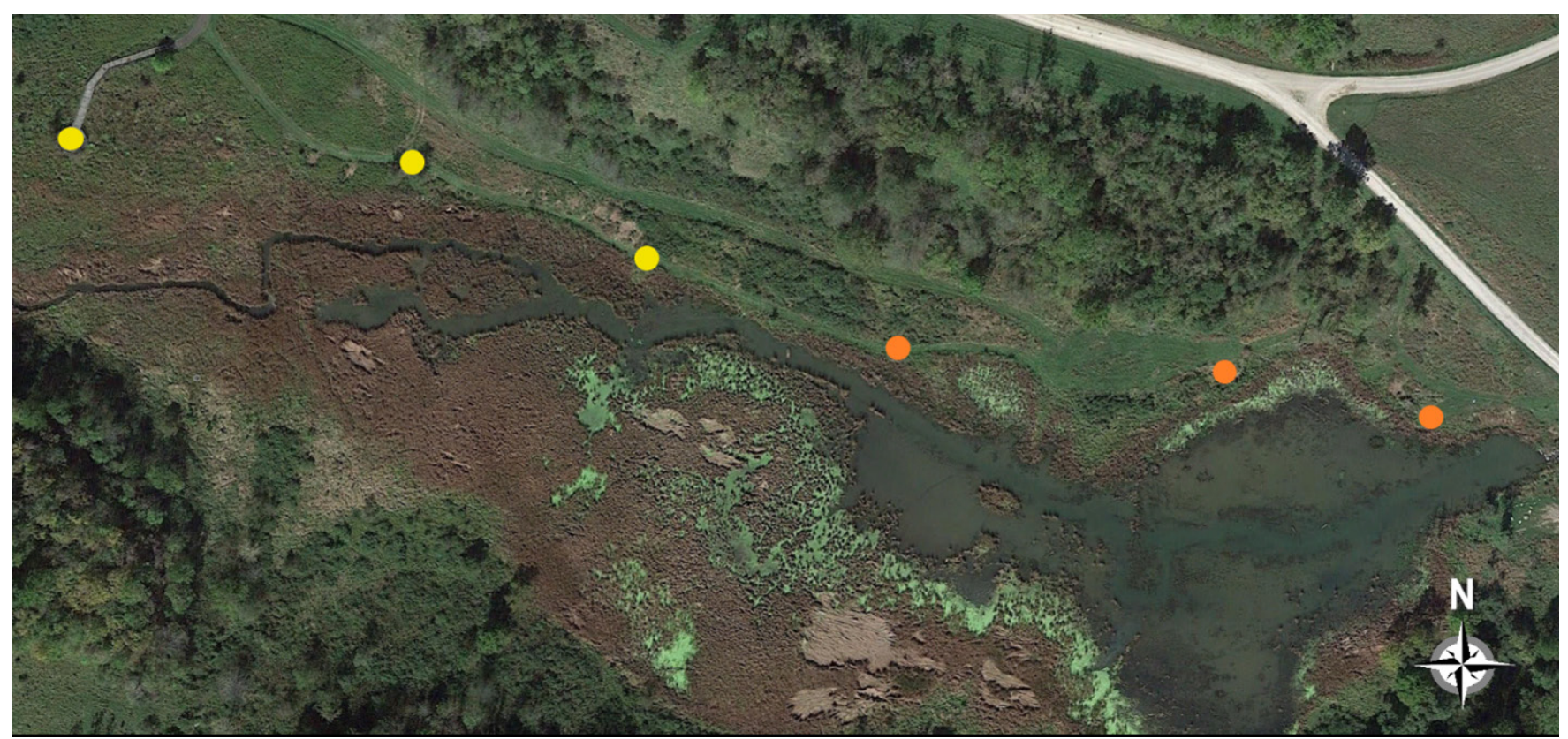

FIGURE 3. Graphic of avian survey passive-period locations at Miller Valley Wetland. Orange dots represent points categorized as open water, yellow dots represent points categorized as closed cattail habitat. The transect was walked from east to west. 
cattail dominance. Each point was categorized "open water" or "closed cattail" based on a visual estimation of the density of cattails present in the middle of the wetland. While no surveys were conducted, the closed cattail portions were estimated to be around $80 \%$ cover, while the open water section was around $5 \%$ cover-the latter featuring only small clumps of cattails (Fig. 4). At each point, all birds heard and seen in a 5-minute passive-period were recorded. The transect was walked from east to west. At the beginning and end of the survey the temperature $\left({ }^{\circ} \mathrm{F}\right)$, wind speed and direction, and cloud cover were recorded for potential use during analysis: to account for weather and temperature effects on the activeness of birds during sampling.

Avian survey analyses were performed using $\mathrm{R}$ software, version 3.5.0, with the lme4 package lmer function for linear mixed effects models (Bates et al. 2015; R Core Team 2018). Boxplots were created in R 3.5.0 (R Core Team 2018).

\section{Vegetative Surveys}

\section{RESULTS}

The restored section of the Miller Valley Wetland was primarily dominated by mixed emergent marsh vegetation, with a secondary community of a cattail (Typha spp.) marsh. The unrestored section of the wetland had a primary community of a cattail marsh, and a secondary vegetation community of non-wetland, non-woody plants, with a modifier of an old field. Therefore, the VIBI-E metrics (for emergent community dominated wetlands) were used to calculate the VIBI score for both transects. For the hydrogeomorphic (HGM) class, the restored section of Miller Valley Wetland was classified as a human impoundment - due to the use of the weir and the controlled drainage system to control hydrology. Due to lack of surface water in the unrestored plot, other than Miller Valley Creek, the unrestored section was classified as a surface water depression. The HGM class influences the quality of habitat assigned to a range of VIBI scores (for further reading about the HGM approach, see Whigham 1999).

A total of 45 species were identified in the restored plot (T1), including 8 species considered adventive, or non-native, in southeastern Ohio (Gara 2016) (Table 1). For the purposes of VIBI, there is not an "invasive" category. However, some of the adventive species, such as autumn olive (Elaeagnus umbellata) and multiflora rose (Rosa multiflora), are considered invasive at The Wilds. The VIBI-E score for T1 was 58 in 2018, an increase of 15 points from the score of 43 in 2017 (Fig. 5A). The VIBI-FQ score also increased to 43 in 2018, versus the score of 19 in 2017, and was the highest score obtained since the VIBI-FQ method of scoring was adopted in 2016 (Fig. 5B). While the vegetative species richness (i.e., the total number of plant species) identified in the plot has decreased from a high of 76 in 2014 to 42 in 2018 (Fig. 5C), the percentage of wetland obligate plants has increased, and the percentage of upland plants has decreased (Fig. 6).

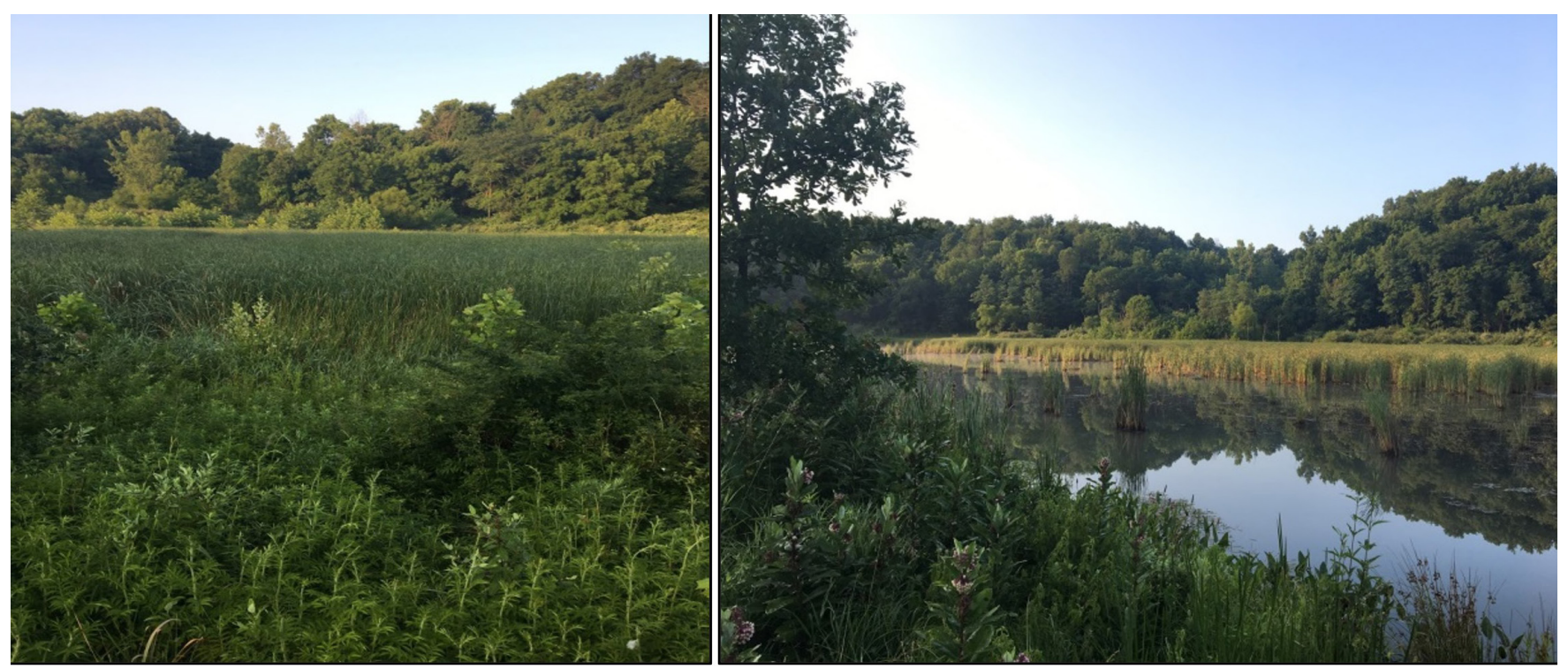

FIGURE 4. Comparison of closed cattail habitat (left) versus open water habitat (right) at Miller Valley Wetland. Both pictures were taken during August 2018. While each photo point is technically within the area that was restored in 2011, the difference in Typha spp. presence is striking-approximately $\mathbf{8 0} \%$ cover in the closed cattail habitat, as opposed to approximately $5 \%$ cover in the open water habitat. 
The unrestored plot (T2) had a vegetative species richness of 33, with 6 of those species considered adventive (Table 2). T2 was given a VIBI-E score of 27 in 2018, a decrease of 2 points from 2017 (Fig. 5A), and a VIBI-FQ score of 21 in 2018, up from a score of 13 in 2017 (Fig. 5B). T2 shows the opposite trend as T1, as the total number of plant species found in the unrestored plot has increased annually (Fig. 5C), while the percentage of wetland obligate species has decreased over time (Fig. 7).

\section{Avian Surveys}

The "open water" habitat had significantly higher avian species richness, with an average of $1.5 \pm 0.5$ species more than the "closed cattail" habitat per survey $\left(\chi^{2}(1)=6.723, p=0.00951\right)$ (Fig. 8). Total species richness was also higher for the open water area, with 3 more species observed in the open water section than in the closed cattail section (Table 3). Though composed of different species, the number of wetland-dependent species was the same in each section $(\mathrm{n}=9)($ Table 3$)$.

Table 1

Year 2018 vegetative species list of the restored plot (T1) of the Miller Valley Wetland in descending order of relative cover

\begin{tabular}{|c|c|c|c|c|c|}
\hline Species & Common name & $\mathrm{Cof}^{\mathrm{a}}$ & Nativity & $\begin{array}{l}\text { Wetland } \\
\text { indicator }{ }^{b, c}\end{array}$ & $\begin{array}{l}\text { Relative } \\
\text { cover }\end{array}$ \\
\hline Potamogeton nodosus & long-leaf pondweed & 3 & native & $\mathrm{OBL}$ & 0.286 \\
\hline Pontederia cordata & pickerelweed & 6 & native & OBL & 0.198 \\
\hline Typha angustifolia & narrow-leaf cat-tail & 0 & adventive & OBL & 0.149 \\
\hline Eleocharis palustris & common spike-rush & 5 & native & OBL & 0.106 \\
\hline Juncus effusus & common rush & 1 & native & FACW+ & 0.068 \\
\hline Scutellaria lateriflora & mad dog skullcap & 3 & native & FACW+ & 0.049 \\
\hline Carex hystericina & porcupine sedge & 5 & native & OBL & 0.0187 \\
\hline Leersia oryzoides & rice cut grass & 1 & native & OBL & 0.018 \\
\hline Agrimonia parviflora & harvestlice & 2 & native & FAC & 0.018 \\
\hline Persicaria hydropiperoides & swamp smartweed & 6 & native & $\mathrm{OBL}$ & 0.013 \\
\hline Boebmeria cylindrica & smallspike false nettle & 4 & native & FACW+ & 0.013 \\
\hline Ludwigia palustris & marsh seedbox & 3 & native & $\mathrm{OBL}$ & 0.008 \\
\hline Rosa multiflora & multiflora rose & 0 & adventive & FACU & 0.008 \\
\hline Carex vulpinoidea & fox sedge & 1 & native & OBL & 0.007 \\
\hline Hibiscus moscheutos & swamp rosemallow & 4 & native & OBL & 0.004 \\
\hline Apocynum cannabinum & Indian hemp & 1 & native & FACU & 0.004 \\
\hline Apocynum androsaemifolium & spreading dogbane & 6 & native & FACU- & 0.004 \\
\hline
\end{tabular}

${ }^{a} \mathrm{CofC}$ indicates the coefficient of conservatism, with lower scores indicating more tolerant species and higher scores for more sensitive species.

${ }^{\mathrm{b}}$ Wetland indicators status reflects the likelihood of a plant being found in a wetland.

OBL: Obligate plant; almost always found in saturated soils.

FACW: Facultative wet plant; almost always occur in areas of prolonged flooding, but on occasion may be found in non-wetlands.

FAC: Facultative plant; occur in a variety of habitats that may be wetland or non-wetland, but are commonly found in wetland habitats.

FACU: Facultative upland plant; typically occur in non-wetland habitats but can occur frequently in wetlands.

UPL: Upland plant; almost never occur in a wetland habitat.

${ }^{\mathrm{c}}$ The $(+)$ or (-) indicates species with frequencies that are intermediate between 2 categories (Lichvar et al. 2012). 
Table 1 (continued)

Year 2018 vegetative species list of the restored plot (T1) of the

Miller Valley Wetland in descending order of relative cover

\begin{tabular}{|c|c|c|c|c|c|}
\hline Species & Common name & $\mathrm{Cof} \mathrm{C}^{\mathrm{a}}$ & Nativity & $\begin{array}{l}\text { Wetland } \\
\text { indicator } b, c\end{array}$ & $\begin{array}{l}\text { Relative } \\
\text { cover }\end{array}$ \\
\hline Scirpus cyperinus & woolgrass & 1 & native & FACW+ & 0.004 \\
\hline Solidago sp. & goldenrod & N/A & adventive & FACW & 0.004 \\
\hline Asclepias incarnata & swamp milkweed & 4 & native & $\mathrm{OBL}$ & 0.001 \\
\hline Sparganium eurycarpum & giant bur-reed & 4 & native & OBL & 0.001 \\
\hline Parthenocissus quinquefolia & Virginia creeper & 2 & native & FACU & 0.001 \\
\hline Astersp. & aster & $\mathrm{N} / \mathrm{A}$ & native & UPL & 0.001 \\
\hline Impatiens capensis & spotted touch-me-not & 2 & native & FACW & 0.001 \\
\hline Verbena hastata & blue vervain & 4 & native & FACW+ & 0.001 \\
\hline Cirsium arvense & Canada thistle & 0 & adventive & FACU & 0.001 \\
\hline Epilobium ciliatum & fringed willowherb & 4 & native & FAC- & 0.001 \\
\hline $\begin{array}{l}\text { Schoenoplectus } \\
\text { tabernaemontani }\end{array}$ & softstem bulrush & 2 & native & $\mathrm{OBL}$ & 0.001 \\
\hline Galium tinctorium & stiff marsh bedstraw & 4 & native & $\mathrm{OBL}$ & 0.001 \\
\hline Persicaria hydropiper & marshpepper knotweed & 1 & native & OBL & 0.001 \\
\hline Mimulus ringens & Allegheny monkeyflower & 4 & native & OBL & 0.001 \\
\hline Carex tribuloides & blunt broom sedge & 4 & native & FACW+ & 0.001 \\
\hline Toxicodendron radicans & poison ivy & 1 & native & FAC & 0.001 \\
\hline Calystegia sepium & hedge bindweed & 1 & native & FAC- & 0.001 \\
\hline Vitis sp. & grape & N/A & native & FACW & 0.001 \\
\hline Elaeagnus umbellata & autumn olive & 0 & adventive & FACU & 0.001 \\
\hline Prunella vulgaris & common selfheal & 0 & native & FACU+ & 0.001 \\
\hline Lythrum salicaria & purple loosestrife & 0 & adventive & FACW+ & 0.001 \\
\hline Lycopus virginicus & Virginia water horehound & 3 & native & $\mathrm{OBL}$ & 0.001 \\
\hline Avenella flexuosa & crinkled hairgrass & 8 & native & UPL & 0 \\
\hline Salix nigra & black willow & 2 & native & FACW+ & 0 \\
\hline Salix alba & white willow & 0 & adventive & FACW & 0 \\
\hline Salix sp. & willow & N/A & native & OBL & $2.34 \times 10^{-5}$ \\
\hline Mentha X piperita & peppermint & 0 & adventive & FACW+ & $2.34 \times 10^{-5}$ \\
\hline Acer negundo & box elder & 3 & native & FAC+ & $2.34 \times 10^{-5}$ \\
\hline
\end{tabular}

${ }^{\mathrm{a}} \mathrm{C}$ of $\mathrm{C}$ indicates the coefficient of conservatism, with lower scores indicating more tolerant species and higher scores for more sensitive species.

${ }^{b}$ Wetland indicators status reflects the likelihood of a plant being found in a wetland.

OBL: Obligate plant; almost always found in saturated soils.

FACW: Facultative wet plant; almost always occur in areas of prolonged flooding, but on occasion may be found in non-wetlands.

FAC: Facultative plant; occur in a variety of habitats that may be wetland or non-wetland, but are commonly found in wetland habitats.

FACU: Facultative upland plant; typically occur in non-wetland habitats but can occur frequently in wetlands.

UPL: Upland plant; almost never occur in a wetland habitat.

${ }^{\mathrm{c}}$ The $(+)$ or $(-)$ indicates species with frequencies that are intermediate between 2 categories (Lichvar et al. 2012). 

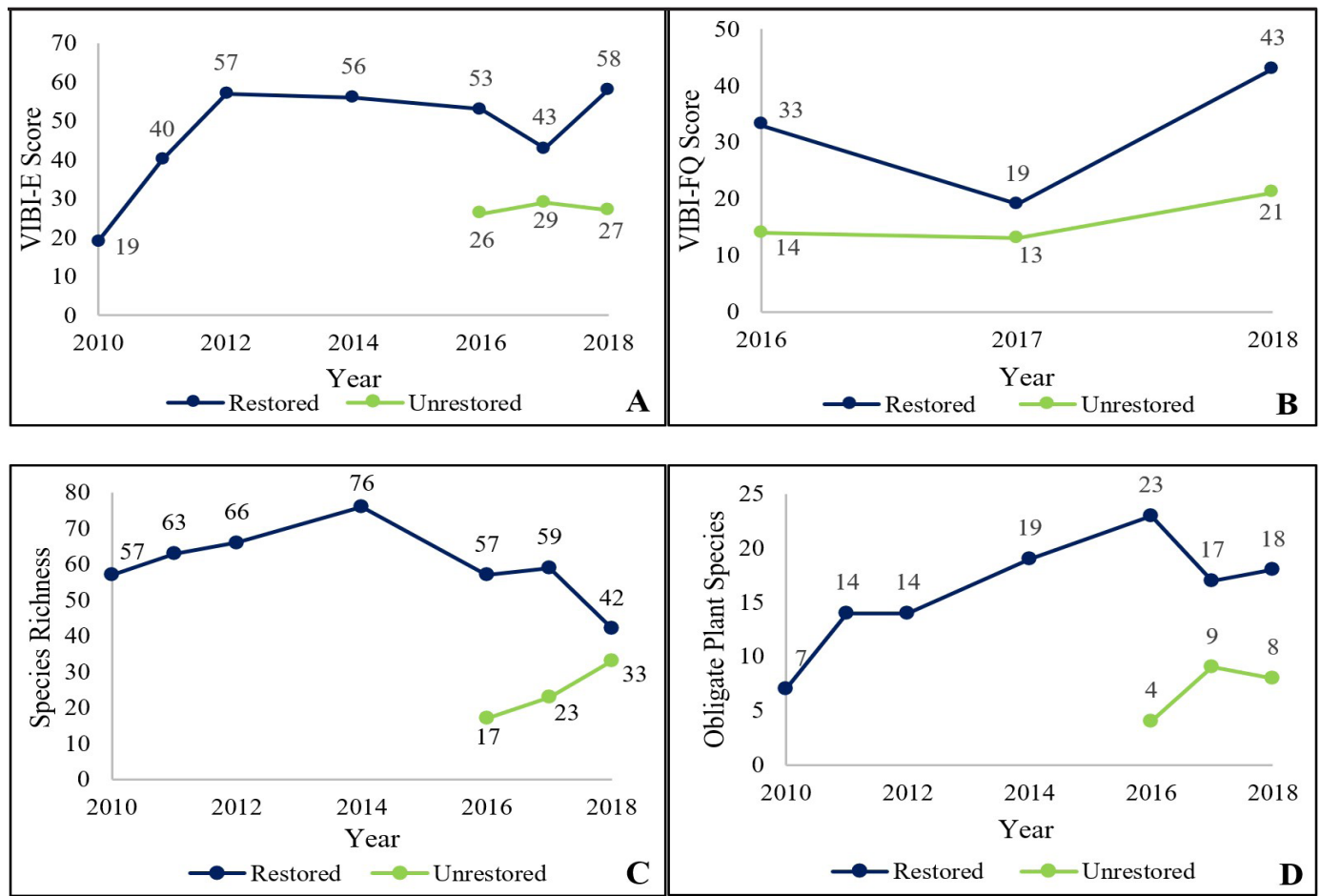

FIGURE 5. Trend lines of the vegetative survey results in the restored plot (T1) since 2010 and the unrestored plot (T2) since 2016 at Miller Valley Wetland. (A) VIBI-E scores. T1 was not surveyed in 2013 and 2015, therefore those years were omitted from the figure. (B) VIBI-FQ scores. The VIBI-FQ method of scoring was adopted in 2016, so previous years have been omitted from the figure. (C) Species richness (or total plant species). (D) Number of wetland obligate species found.

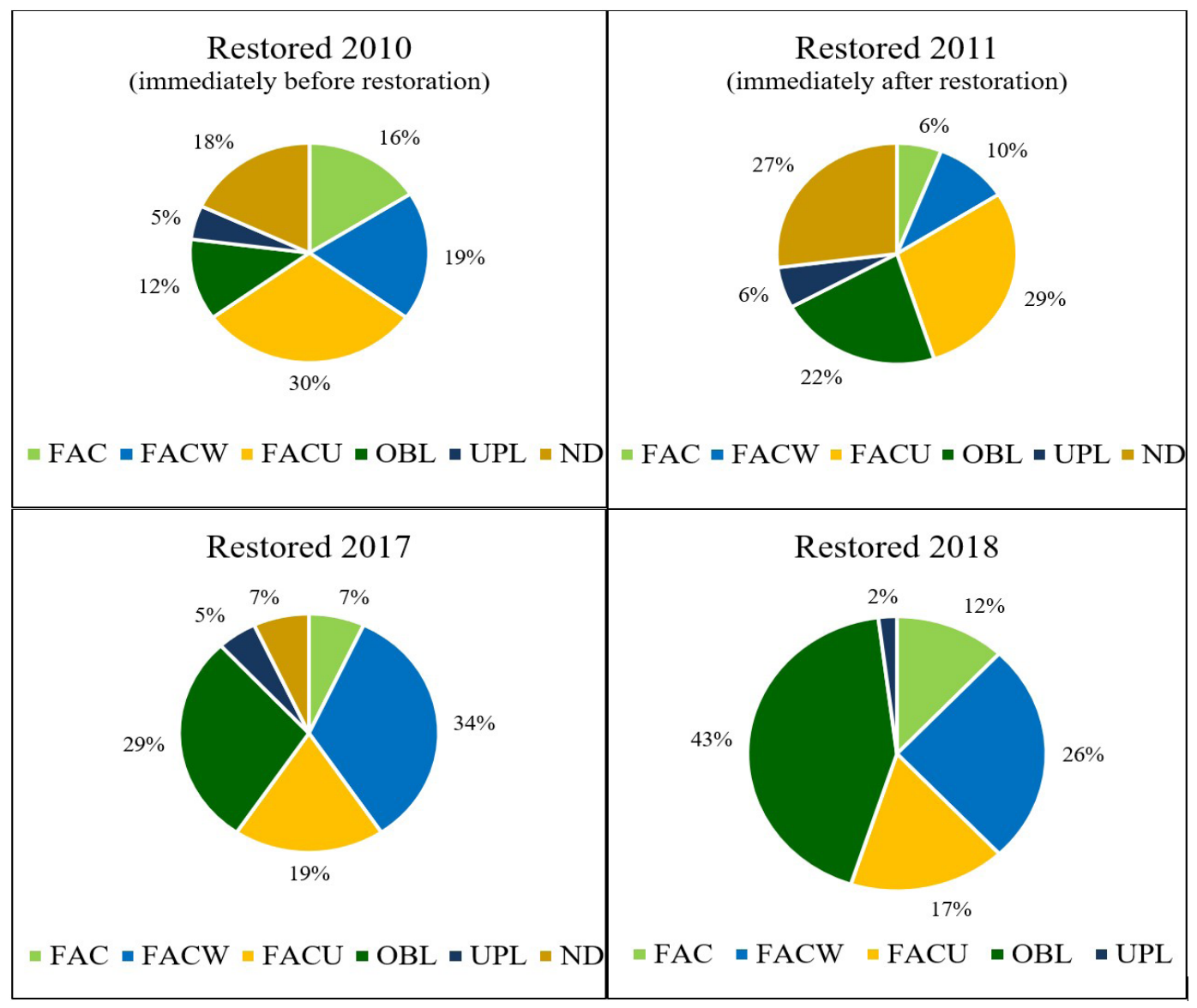

FIGURE 6. Changes in wetland indicator status of the plant community in the restored plot (T1). The chart from 2010 represents the wetland before restoration, while the chart from 2011 represents the wetland immediately after the restoration project. The percentage of wetland obligate $(O B L)$ plants has increased since the restoration project. FAC = facultative, FACW = facultative wetland, FACU = facultative upland, UPL = upland, ND = not determined. 
Table 2

Year 2018 vegetative species list of the unrestored plot (T2) of the Miller Valley Wetland in descending order of relative cover

\begin{tabular}{|c|c|c|c|c|c|}
\hline Species & Common name & $\mathrm{Cof} \mathrm{C}^{\mathrm{a}}$ & Nativity & $\begin{array}{l}\text { Wetland } \\
\text { indicator } b, c\end{array}$ & $\begin{array}{l}\text { Relative } \\
\text { cover }\end{array}$ \\
\hline Typha angustifolia & narrow-leaf cat-tail & 0 & adventive & OBL & 0.333 \\
\hline Impatiens capensis & spotted touch-me-not & 2 & native & FACW & 0.113 \\
\hline Solanum dulcamara & bittersweet nightshade & 0 & adventive & FAC- & 0.010 \\
\hline Boehmeria cylindrica & smallspike false nettle & 4 & native & FACW+ & 0.086 \\
\hline Cirsium vulgare & bull thistle & 0 & adventive & FACU- & 0.056 \\
\hline Asclepias syriaca & common milkweed & 1 & native & FACU- & 0.042 \\
\hline Cuscuta gronovii & scaldweed & 3 & native & FACW+ & 0.040 \\
\hline Bidens connata & purplestem beggarticks & 3 & native & FACW+ & 0.032 \\
\hline Lycopus virginicus & Virginia water horehound & 3 & native & OBL & 0.024 \\
\hline Parthenocissus quinquefolia & Virginia creeper & 2 & native & FACU & 0.024 \\
\hline Onoclea sensibilis & sensitive fern & 2 & native & FACW & 0.020 \\
\hline Rosa multiflora & multiflora rose & 0 & adventive & FACU & 0.020 \\
\hline Rubus allegheniensis & Allegheny blackberry & 1 & native & FACU- & 0.020 \\
\hline Calystegia sepium & hedge bindweed & 1 & native & FAC- & 0.016 \\
\hline Lycopus americanus & American water horehound & 3 & native & $\mathrm{OBL}$ & 0.016 \\
\hline Bidens frondosa & devil's beggartick & 2 & native & FACW & 0.008 \\
\hline Vernonia gigantea & tall ironweed & 2 & native & FAC & 0.008 \\
\hline Conoclinium coelestinum & blue mistflower & 3 & native & FAC & 0.006 \\
\hline Vitis aestivalis & summer grape & 4 & native & FACU & 0.005 \\
\hline Cirsium arvense & Canada thistle & 0 & adventive & FACU & 0.005 \\
\hline Toxicodendron radicans & poison ivy & 1 & native & FAC & 0.005 \\
\hline Acer rubrum & red maple & 2 & native & FAC & 0.004 \\
\hline Agrimonia parviflora & harvestlice & 2 & native & FAC & 0.004 \\
\hline Verbesina alternifolia & wingstem & 5 & native & FAC & 0.004 \\
\hline Persicaria hydropiperoides & swamp smartweed & 6 & native & OBL & 0.003 \\
\hline Castanea pumila & chinquapin & 0 & adventive & UPL & 0.002 \\
\hline Eupatorium perfoliatum & common boneset & 3 & native & FACW+ & 0.002 \\
\hline Galium tinctorium & stiff marsh bedstraw & 4 & native & $\mathrm{OBL}$ & 0.002 \\
\hline
\end{tabular}

${ }^{\mathrm{a}} \mathrm{C}$ ofC indicates the coefficient of conservatism, with lower scores indicating more tolerant species and higher scores for more sensitive species.

${ }^{\mathrm{b}}$ Wetland indicators status reflects the likelihood of a plant being found in a wetland. OBL: Obligate plant; almost always found in saturated soils.

FACW: Facultative wet plant; almost always occur in areas of prolonged flooding, but on occasion may be found in non-wetlands.

FAC: Facultative plant; occur in a variety of habitats that may be wetland or non-wetland, but are commonly found in wetland habitats.

FACU: Facultative upland plant; typically occur in non-wetland habitats but can occur frequently in wetlands. UPL: Upland plant; almost never occur in a wetland habitat.

${ }^{c}$ The $(+)$ or $(-)$ indicates species with frequencies that are intermediate between 2 categories (Lichvar et al. 2012). 
Table 2 (continued)

Year 2018 vegetative species list of the unrestored plot (T2) of the Miller Valley Wetland in descending order of relative cover

\begin{tabular}{llllll}
\hline \hline Species & Common name & Cof C $^{\text {a }}$ & Nativity & $\begin{array}{l}\text { Wetland } \\
\text { indicator }\end{array}$ & $\begin{array}{l}\text { Relative } \\
\text { cover }\end{array}$ \\
\hline Lonicera oblongifolia & swamp fly honeysuckle & 9 & native & OBL & 0.002 \\
Acer negundo & box elder & 3 & native & FAC+ & 0.001 \\
Mimulus ringens & Allegheny monkeyflower & 4 & native & OBL & 0.001 \\
Samolus valerandi & seaside brookweed & 4 & native & OBL & $1.13 \times 10^{-5}$ \\
Senna hebecarpa & American senna & 4 & native & FAC & $1.13 \times 10^{-5}$ \\
\hline
\end{tabular}

${ }^{a} \mathrm{CofC}$ indicates the coefficient of conservatism, with lower scores indicating more tolerant species and higher scores for more sensitive species.

${ }^{\mathrm{b}}$ Wetland indicators status reflects the likelihood of a plant being found in a wetland.

OBL: Obligate plant; almost always found in saturated soils.

FACW: Facultative wet plant; almost always occur in areas of prolonged flooding, but on occasion may be found in non-wetlands.

FAC: Facultative plant; occur in a variety of habitats that may be wetland or non-wetland, but are commonly found in wetland habitats.

FACU: Facultative upland plant; typically occur in non-wetland habitats but can occur frequently in wetlands.

UPL: Upland plant; almost never occur in a wetland habitat.

${ }^{\mathrm{c}}$ The $(+)$ or $(-)$ indicates species with frequencies that are intermediate between 2 categories (Lichvar et al. 2012).

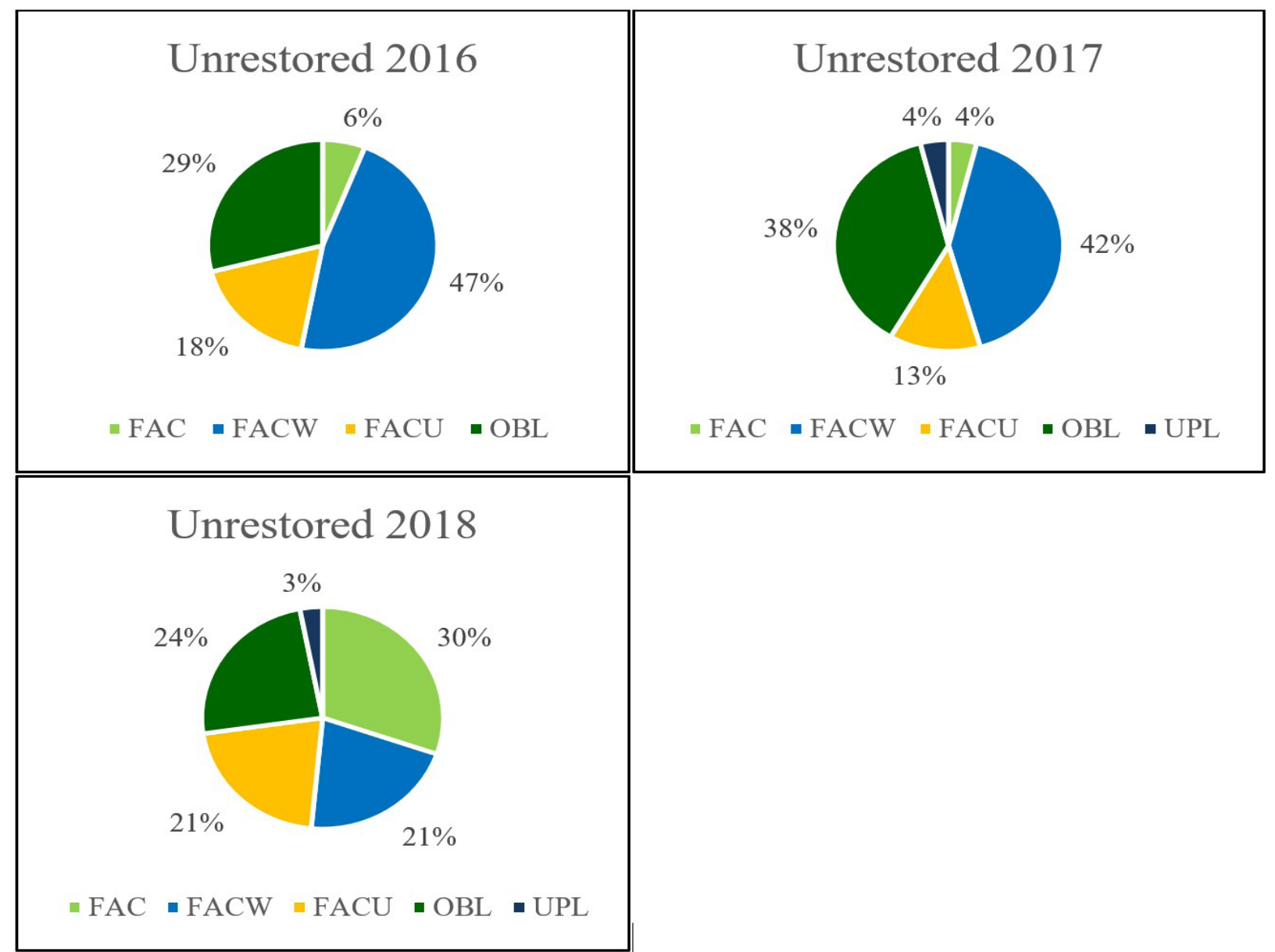

FIGURE 7. Annual changes in wetland indicator status of the plant community in the unrestored plot (T2). T2 was established in 2016. The percentage of wetland obligate $(O B L)$ plants has decreased over time. $F A C=$ facultative, $F A C W=f a c u l t a t i v e$ wetland, FACU $=$ facultative upland, $\mathrm{UPL}=$ upland. 
Table 3

Year 2018 avian species list recorded in Miller Valley Wetland by section

\begin{tabular}{|c|c|c|}
\hline Open water & Both areas & Closed cattails \\
\hline American Redstart & American Crow & American Woodcock ${ }^{a}$ \\
\hline Baltimore Oriole & American Goldfinch & Cedar Waxwing \\
\hline Belted Kingfisher $^{a}$ & American Robin & House Sparrow \\
\hline Indigo Bunting & Barn Swallow & Virginia Rail $^{\mathrm{a}}$ \\
\hline American Tree Sparrow & American Black Duck ${ }^{a}$ & Wild Turkey \\
\hline Trumpeter Swan ${ }^{a}$ & Chipping Sparrow & \\
\hline Turkey Vulture & Common Grackle & \\
\hline \multirow[t]{23}{*}{ Yellow Warbler } & Common Yellowthroat $^{\mathrm{a}}$ & \\
\hline & Eastern Kingbird & \\
\hline & Eastern Towhee & \\
\hline & European Starling & \\
\hline & Field Sparrow & \\
\hline & Great Blue Heron $^{\mathrm{a}}$ & \\
\hline & Green Heron $^{a}$ & \\
\hline & Grey Catbird & \\
\hline & House Wren & \\
\hline & Killdeer $^{\mathrm{a}}$ & \\
\hline & Mourning Dove & \\
\hline & Northern Cardinal & \\
\hline & Pileated Woodpecker & \\
\hline & Red-eyed Vireo & \\
\hline & Red-winged Blackbird & \\
\hline & Eastern Screech-Owl & \\
\hline & Song Sparrow & \\
\hline & Swamp Sparrow ${ }^{a}$ & \\
\hline & Tree Swallow ${ }^{\mathrm{a}}$ & \\
\hline & Tufted Titmouse & \\
\hline & White-eyed Vireo & \\
\hline & Wood Thrush & \\
\hline & Yellow-billed Cuckoo & \\
\hline
\end{tabular}

\footnotetext{
${ }^{a}$ Water birds and wetland-dependent species are shown in bold (as denoted in ODNR 2006).
} 


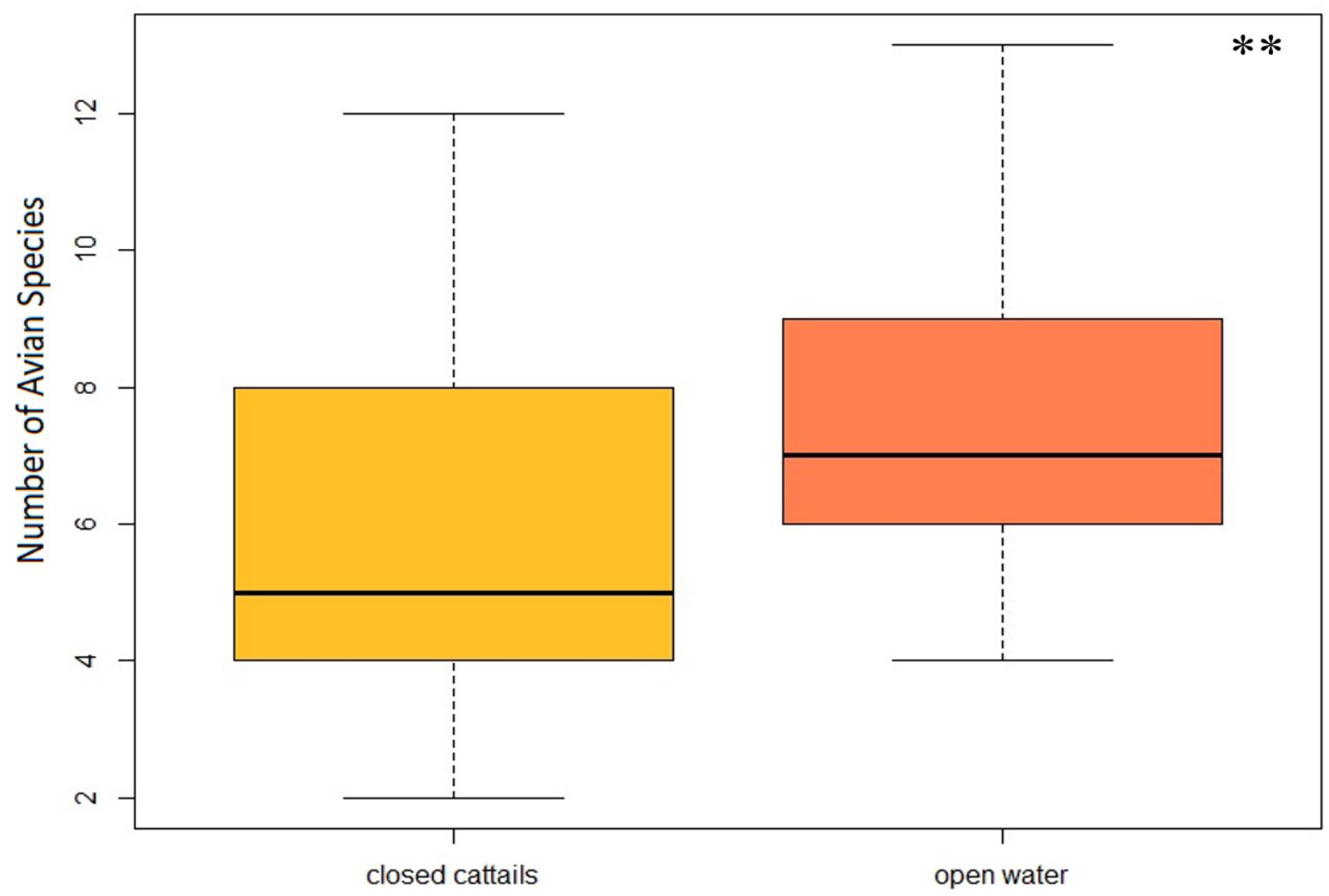

Region

FIGURE 8. Avian species richness between open water and closed cattail habitat at Miller Valley Wetland. Species richness was calculated by averaging the 3 survey points per wetland area, obtained over 8 total surveys.

** Symbolize $p<0.001$, linear effects model.

\section{DISCUSSION}

\section{Vegetative Surveys}

Using the traditional Vegetation Index of Biotic Integrity for Emergent Vegetation (VIBI-E), the restored wetland is considered a wetland habitat which can support a balanced, adaptive, and integrated community. The unrestored section is considered a restorable wetland habitat, which is a degraded wetland that still has the potential to become a wetland habitat (see Peet et al. 1998 for original scoring table; Mack and Gara 2015). The relatively low quality of the wetland sections - the restored section scored at the lower range of the wetland habitat category-is unsurprising, as many studies have found that vegetation takes significantly longer than 10 years to reach comparable states to reference wetlands (Seabloom and van der Valk 2003; Jones and Schmitz 2009; Matthews et al. 2009; Moreno-Mateos et al. 2012; Moreno-Mateos et al. 2015). The plant richness of the restored section appears to be following the trend identified by
Moreno-Mateos et al. (2012) in which plant richness increases for 5 years after restoration, then decreases again for another 5 years; this is similar to the overall loss of richness observed in wetland emergent zones in Minnesota after 13 years (Robertson et al. 2018). These trends appear to be due to some of the planted community failing to thrive, then recolonization of unplanted and invasive species, and finally domination by the invasive species. A review of wetland responses to different restoration approaches found that the structure of biotic assemblages recovered to approximately $80 \%$ of reference wetland levels after 10 years when flow reestablishment and revegetation techniques are used (Moreno-Mateos et al. 2015); the trend of modest improvement at Miller Valley Wetland indicates that it is generally following this same trajectory. Robertson et al. (2018) observed a loss of cover in emergent communities due to increased open water, a trend also observed in Miller Valley Wetland. Consequently, the general upward trend of increased wetland obligative plants 
in the restored section, likely due to the increase in open water, is also consistent with trends observed in restored Illinois wetlands (Meyer et al. 2010).

Since 2016, muskrats (Ondatra zibethicus) have been observed recolonizing Miller Valley Wetland, and their feeding activity may be limiting the recolonization of Typha spp. into the restored section. Cattail is known to be a favorite food of muskrats of all ages - and muskrats have been shown to eat all parts of the plant at different times, including the underwater portions (Errington 1941). Muskrats have been recommended for invasive cattail management, as they are highly efficient, if imprecise, grazers (Ball 1990; Svedarsky et al. 2019). A quantitative study of muskrat activity in Miller Valley Wetland may be useful in testing the role of muskrats in controlling the spread of cattail.

In the unrestored section, there has been an increase in facultative upland and facultative, or generalist, plant species in the 3 years of monitoring. The number of wetland obligate and facultative wetland plants have decreased, thus demonstrating an opposing trend to the restored section. The unrestored section lacks surface water other than a small stream, so the hydrological regime does not support wetland obligate species. These differences are not only indicative of the health of the wetland, they also demonstrate the different trajectories of the 2 sections. So far, the unrestored section-on its own-is not increasing in quality.

While the VIBI scores have generally increased since 2017 (except the VIBI-E score of the unrestored section), fluctuations in the vegetative community are expected; therefore, continued monitoring and potentially further restoration is required to determine if the upward trajectory will persist (Zedler 2000; Seabloom and van der Valk 2003; Aronson and Galatowitsch 2008; Matthews and Spyreas 2010; Price 2016; Robertson et al. 2018). From personal observation, it is clear Typha spp. is invading the restored portion of the wetland due to the close physical proximity of the unrestored section, as well as the existing seedbank from before the restoration. Typha spp., if not actively managed, has been found to significantly increase around 5 to 8 years after restoration efforts (Galatowitsch et al. 1999; Aronson and Galatowitsch 2008; Meyer et al. 2010; Robertson et al. 2018). Additionally, restored wetland sites in close proximity have been shown to converge or homogenize (Aronson and Galatowitsch
2008; Matthews and Spyreas 2010; Price 2016; Robertson et al. 2018). The lack of other restored wetlands, in close proximity to the current study site, further disadvantages the restored section of Miller Valley Wetland in resisting the encroachment of invasive species from the adjoining unrestored section. The risk is exacerbated by the fact that the unrestored section is upstream of the restored section, which facilitates the spread of invasive species (Baldwin 2004; Moreno-Mateos et al.2008). Finally, Seabloom and van der Valk (2003) found that the weak dispersal abilities of desired wetland plants are the largest barriers to recolonization and early succession of restored wetlands; thus, these authors recommend restoration of entire wetland complexes to minimize the isolation between wetlands. While the approaching Typha spp. has reached the restored VIBI plot at Miller Valley Wetland, the muskrats may be suppressing new recruitment of Typha in much of the rest of the restored section for now (pers. obs.). While literature is sparse, muskrats have been found to preferentially reduce Typha biomass and facilitate increases in open water area (Proulx and Gilbert 1983; Connors et al. 2000). However, without another round of invasive removal, what progress the restored section has experienced is in peril.

\section{Avian Surveys}

Animal assemblages (unlike plant assemblages) have been found to recover quickly in restored wetlands, especially when the restoration included flow re-establishment and revegetation-as was the case for Miller Valley Wetland (Moreno-Mateos et al.2012). The data from these avian surveys reflected the findings of Seigel et al. (2005); that study found a significant increase in species richness 5 years after the restoration of an urban tidal marsh, when compared to pre-restoration data. Additionally, Brown and Smith (1998) found that total avian species richness was similar between a recently restored wetland and a high-quality reference site, though the species composition differed; the current study mirrors this when comparing the avian species richness of the restored and unrestored sections, though neither could be called "high quality." The higher avian species richness per survey in the "open water" habitat at Miller Valley Wetland is likely due to increased habitat heterogeneity, as it is known that birds prefer wetlands with high vegetative heterogeneity 
over wetlands dominated by tall, monotypic stands (Kantrud 1986; Seigel et al. 2005; Lehikoinen et al. 2017). This response can be used to inform future invasive removal plans: if bird surveys are continued and avian species richness decreases, it can indicate invasive removal may be necessary. Therefore, these avian surveys can be used as a supplement to the VIBI vegetation surveys to evaluate the health of Miller Valley Wetland.

It is recommended that future bird surveys be conducted in the Miller Valley Wetland. These surveys should occur over a longer period, incorporate multiple seasons, and include breeding periods and overwintering of different species. Such a study would help determine the importance of Miller Valley Wetland to the avian community. Finally, a Virginia Rail (Rallus limicola) was detected during the current study - these secretive birds are often a focus of targeted wetland management, and knowing more about their occupancy of Miller Valley Wetland will aid future vegetation management decisions.

The apparently successful restoration of Miller Valley Wetland as a wetland bird habitat-due to the observed number of wetland-dependent species and increase in species richness-also supports the total restoration of the wetland. The size of a restored habitat is often correlated with the species of wetland birds that will use the site, with larger wetlands typically boasting greater species diversity (Gibbs et al. 1991; VanRees-Siewert and Dinsmore 1996; Brown and Smith 1998; Naugle et al. 1999; Fletcher et al. 2007; Sebastián-González and Green 2014). Managed wetlands have higher detection and occupancy rates than unmanaged sites, including for several at-risk and priority bird species like the Least Bittern (Ixobrychus exilis) and Sora (Porzana carolina) (Hagy and McClain 2015; Tozer et al. 2018). Moreover, while cost is typically a barrier to restoration and management projects, a direct, positive correlation has been found between the amount of money spent on overgrowth removal measures and bird abundance (Lehikoinen et al. 2017). It is expected that the total restoration of Miller Valley Wetland, in conjunction with vegetation management in the already-restored section, would benefit the avian community.

\section{Conclusion}

As many wetland researchers have previously concluded, the 5-year monitoring period required by laws (such as the Clean Water Act) in the United States is inadequate to fully understand the progress and success of a wetland restoration (Zedler 2000; Kellogg and Bridgham 2002; Ruiz-Jaen and Aide 2005; Aronson and Galatowitsch 2008; Matthews and Spyreas 2010; Price 2016; Robertson et al. 2018). The current study at the Miller Valley Wetland corroborates these observations; if monitoring had been stopped after only 5 years, trends at that time would have indicated a misleadingly positive image of the success of the restoration. Additionally, Miller Valley Wetland illustrates the necessity of fully restoring a wetland-while the partial restoration of the wetland does provide a unique research opportunity, the unrestored section is contributing negatively to the future heal th of the restored section. The upstream location of the unrestored section is likely contributing to the recolonization of Typha spp. into the restored section (Galatowitsch et al. 1999; Baldwin 2004; Aronson and Galatowitsch 2008; Moreno-Mateos et al. 2008; Meyer et al. 2010; Robertson et al. 2018). Therefore, Miller Valley Wetland demonstrates the need not only for continued monitoring and invasive control, but also the full restoration of the total area of the wetland. The avian community would also benefit from the full restoration: while vegetation control and open-water expansion would benefit some bird species more than others, higher species richness and diversity are associated with both larger restorations and higher habitat heterogeneity (VanRees-Siewert and Dinsmore 1996; Brown and Smith 1998; Seigel et al. 2005; Fletcher et al. 2007; Sebastián-González and Green 2014; Lehikoinen et al. 2017).

\section{ACKNOWLEDGEMENTS}

The largest thanks go to the multitude of reviewers who gave their invaluable critiques, which greatly improved this paper. Thank you to Denison University for its financial support during this apprenticeship. We give our gratitude to apprentice Liz Sautter for her many hours of assistance in both the field and the lab. Thank you to Alexys Nolan for her aid in plant identification. Finally, thank you to Valerie Repp, her OWLs, and all other 2018 summer "apprenti" for their help with this project. 


\section{LITERATURE CITED}

Andreas BK, Mack JJ, McCormac JS. 2004. Floristic quality assessment index (FQAI) for vascular plants and mosses for the State of Ohio. Columbus (OH): Ohio Environmental Protection Agency, Division of Surface Water, Wetland Ecology Group. 219 p. Available from Ohio EPA at: https://www.epa.ohio.gov/portals/35/wetlands/Ohio_FQAI.pdf

Aronson MFJ, Galatowitsch S. 2008. Long-term vegetation development of restored prairie pothole wetlands. Wetlands. 28(4):883-895. https://doi.org/10.1672/08-142.1

Baldwin AH. 2004. Restoring complex vegetation in urban settings: the case of tidal freshwater marshes. Urban Ecosyst. 7(2):125-137. https://doi.org/10.1023/B:UECO.0000036265.86125.34

Ball JP. 1990. Influence of subsequent flooding depth on cattail control by burning and mowing. J Aquat Plant Manage. 28:32-36.

Bates D, Mächler M, Bolker B, Walker S. 2015. Fitting linear mixed-effects models using lme4. J Stat Softw. 67(1):1-48. https://doi.org/10.18637/jss.v067.i01

Boers AM, Frieswyk CB, Verhoeven JTA, Zedler JB. 2006. Contrasting approaches to the restoration of diverse vegetation in herbaceous wetlands. In: Bobbink R, Beltman B, Verhoeven JTA, Whigham DF, editors. Wetlands: functioning, biodiversity conservation, and restoration. Ecological studies (analysis and synthesis), vol. 191. Berlin (Germany): Springer. p. 225-246. https://doi.org/10.1007/978-3-540-33189-6_10

Brandt EC. 2013. Relating plant spatial pattern, plant biodiversity, and ecosystem function to management practices in experimental restored wetlands [honors paper]. [Oberlin $(\mathrm{OH})]$ : Oberlin College. https://digitalcommons.oberlin.edu/honors/309

Brown SC. 2008. Vegetation similarity and avifaunal food value of restored and natural marshes in northern New York. Restor Ecol. 7(1):56-68. https://doi.org/10.1046/j.1526-100X.1999.07107.x

Brown SC, Smith CR. 1998. Breeding season bird use of recently restored versus natural wetlands in New York. J Wildlife Manage. 62(4):1480-1491. https://doi.org/10.2307/3802014

Brusati ED, DuBowy PJ, Lacher TE Jr. 2001. Comparing ecological functions of natural and created wetlands for shorebirds in Texas. Waterbirds. 24(3):371-380. https://doi.org/10.2307/1522067

[CMLAR] Compensatory Mitigation for Losses of Aquatic Resources, General compensatory mitigation requirements, 33 CFR $\$ 332.3$ (Apr. 10, 2008) [accessed 2018 Jun 18]. https://www.law.cornell.edu/cfr/text/33/332.3

Connors LM, Kiviat E, Groffman PM, Ostfeld RS. 2000. Muskrat (Ondatra zibethicus) disturbance to vegetation and potential net nitrogen mineralization and nitrification rates in a freshwater tidal marsh. Am Midl Nat. 143(1):53-63. https://doi.org/10.1674/0003-0031(2000)143[0053:MOZDTV]2.0.CO;2

Conway CJ. 2011. Standardized North American marsh bird monitoring protocol. Waterbirds. 34(3):319-346.

https://doi.org/10.1675/063.034.0307
Cronk JK, Fennessy MS. 2001. Wetland plants: biology and ecology. Boca Raton (FL): CRC Press. 482 p. ISBN13: 978-1566703727. https://doi.org/10.1201/9781420032925

Dahl TE. 2006. Status and trends of wetlands in the conterminous United States 1998 to 2004. Washington (DC): United States Department of the Interior, Fish and Wildlife Service. $112 \mathrm{p}$. https://hdl.handle.net/2027/mdp.39015069137969

Delphey PJ. 1991. A comparison of the bird and aquatic macroinvertebrate communities between restored and 'natural' Iowa prairie wetlands [master's thesis]. [Ames (IA)]: Iowa State University. https://doi.org/10.31274/rtd-180813-12118

Delphey PJ, Dinsmore JJ. 1993. Breeding bird communities of recently restored and natural prairie potholes. Wetlands. 13(3):200-206.

https://doi.org/10.1007/BF03160881

Desrochers DW, Keagy JC, Cristol DA. 2008. Created versus natural wetlands: avian communities in Virginia salt marshes. Ecoscience. 15(1):36-43.

https://doi.org/10.2980/1195-6860(2008)15[36:CVNWAC]2.0.CO;2

Errington PL. 1941. Versatility in feeding and population maintenance of the muskrat. J Wildlife Manage. 5(1):68-89. https://doi.org/10.2307/3796056

Fletcher R, Cilimburg A, Hutto R. 2007. Evaluating habitat restoration at O'dell Creek using bird communities: 2006 report. Missoula (MT): University of Montana, Division of Biological Sciences, Avian Science Center. 30 p.

Furness RW. 1993. Birds as monitors of pollutants. In: Furness RW, Greenwood JJD, editors. Birds as monitors of environmental change. Dordrecht (NL): Springer. p. 86-143. https://doi.org/10.1007/978-94-015-1322-7_3

Galatowitsch SM, Anderson NO, Ascher PD. 1999. Invasiveness in wetland plants in temperate North America. Wetlands. 19(4):733-755. https://doi.org/10.1007/BF03161781

Gara BD. 2016. Streamlined vegetation monitoring to assess the condition of Ohio's wetlands. Columbus $(\mathrm{OH})$ : Ohio Environmental Protection Agency, Division of Surface Water, Wetland Ecology Group. 56 p. Available at: https://www.ohwetlands.org/uploads/5/0/6/9/50693061/ streamlined_vegetation_monitoring_to_assess_the_ condition_of_ohio\%E2\%80\%99s_wetlands.pdf

Gibbs JP, Longcore JR, McAuley DG, Ringelman JK. 1991. Use of wetland habitats by selected nongame water birds in Maine. Washington (DC): US Department of the Interior, US Fish and Wildlife Service, Patuxent Wildlife Research Center. 57 p. Report No.: Fish and Wildlife Research No. 9. Available from USGS Publication Warehouse: https://pubs.er.usgs.gov/publication/5230225 
Hagy HM (Forbes Biological Station, Frank C. Bellrose Waterfowl Research Center, Havana, IL), McClain DR. 2015. Wetland management strategies that maximize marsh bird use in the Midwest: Annual Report Period: 1 July 2014 - 30 June 2015. Washington (DC): US Department of the Interior, US Fish and Wildlife Service. 12 p. Report No.: Illinois Natural History Survey Technical Report 2015 (29). Contract No.: F14AP00485. Available from:

https://www.ideals.illinois.edu/bitstream/handle/2142/88327/ INHS2015_29.pdf?sequence=2

Johnston CA, Zedler JB, Tulbure MG, Frieswyk CB, Bedford BL, Vaccaro L. 2009. A unifying approach for evaluating the condition of wetland plant communities and identifying related stressors. Ecol Appl. 19(7):1739-1757.

https://doi.org/10.1890/08-1290.1

Jones HP, Schmitz OJ. 2009. Rapid recovery of damaged ecosystems. PloS ONE. 4(5):e5653.

https://doi.org/10.1371/journal.pone.0005653

Kantrud HA. 1986. Effects of vegetation manipulation on breeding waterfowl in prairie wetlands -- a literature review. Washington (DC): US Department of the Interior, US Fish and Wildlife Service, Northern Prairie Wildlife Research Center. 15 p. Report No.: Fish and Wildlife Technical Report 3. Available from USGS Publication Warehouse: https://pubs.er.usgs.gov/publication/2000113

Kellogg CH, Bridgham SD. 2002. Colonization during early succession of restored freshwater marshes. Can J Botany. 80(2):176-185.

https://doi.org/10.1139/b02-001

Kennedy TA, Naeem S, Howe KM, Knops JMH, Tilman D, Reich P. 2002. Biodiversity as a barrier to ecological invasion. Nature. 417:636-638.

https://doi.org/10.1038/nature00776

Kusler JA, Kentula ME, editors. 1990. Wetland creation and restoration: the status of the science. Washington (DC): Island Press. 594 p.

Lehikoinen P, Lehikoinen A, Mikkola-Roos M, Jaatinen K. 2017. Counteracting wetland overgrowth increases breeding and staging bird abundances. Sci Rep-UK. 7:41391. https://doi.org/10.1038/srep41391

LePage BA, editor. 2011. Wetlands: integrating multidisciplinary concepts. Netherlands: Springer. 261 p. https://doi.org/10.1007/978-94-007-0551-7

Lichvar RW, Melvin NC, Butterwick ML, Kirchner WN. 2012. National wetland plant list indicator rating definitions. Hanover (NH): US Army Corps of Engineers, Engineer Research and Development Center, Cold Regions Research and Engineering Laboratory. 7 p. Report No.: ERDC/ CRREL TN-12-1. Available from: Available from NTIS, Springfield, Virginia 22161.

Mack JJ, Gara BD. 2015. Integrated wetland assessment program. Part 9: Field manual for the vegetation index of biotic integrity for wetlands v. 1.5. Columbus $(\mathrm{OH})$ : Ohio Environmental Protection Agency, Division of Surface Water, Wetland Ecology Group. 124 p. Report No.: Ohio EPA Technical Report WET/2015-2. Available from Ohio EPA at: https://epa.ohio.gov/portals/35/wetlands/Part9_field_ manual_v1_5rev15aug15.pdf
Matthews JW, Spyreas G. 2010. Convergence and divergence in plant community trajectories as a framework for monitoring wetland restoration progress. J Appl Ecol. 47(5):1128-1136. https://doi.org/10.1111/j.1365-2664.2010.01862.x

Matthews JW, Spyreas G, Endress AG. 2009. Trajectories of vegetation-based indicators used to assess wetland restoration progress. Ecol Appl. 19(8):2093-2107.

https://doi.org/10.1890/08-1371.1

Meyer CK, Whiles MR, Baer SG. 2010. Plant community recovery following restoration in temporally variable riparian wetlands. Restor Ecol. 18(1):52-64.

https://doi.org/10.1111/j.1526-100X.2008.00451.x

Mitsch WJ, Day JW Jr. 2006. Restoration of wetlands in the Mississippi-Ohio-Missouri (MOM) River basin: experience and needed research. Ecol Eng. 26(1):55-69.

https://doi.org/10.1016/j.ecoleng.2005.09.005

Moreno-Mateos D, Mander Ü, Comín FA, Pedrocchi C, Uuemaa E. 2008. Relationships between landscape pattern, wetland characteristics, and water quality in agricultural catchments. J Environ Qual. 37(6):2170-2180.

https://doi.org/10.2134/jeq2007.0591

Moreno-Mateos D, Meli P, Vara-Rodríguez MI, Aronson J. 2015. Ecosystem response to interventions: lessons from restored and created wetland ecosystems. J Appl Ecol. 52(6):1528-1537.

https://doi.org/10.1111/1365-2664.12518

Moreno-Mateos D, Power ME, Comín FA, Yockteng R. 2012. Structural and functional loss in restored wetland ecosystems. PLoS Biol. 10(1):e1001247. https://doi.org/10.1371/journal.pbio.1001247

Naugle DE, Higgins KF, Nusser SM, Johnson WC. 1999. Scaledependent habitat use in three species of prairie wetland birds. Landscape Ecol. 14(3):267-276. https://doi.org/10.1023/A:1008088429081

[ODNR] Ohio Department of Natural Resources, Division of Wildlife. 2006. Waterbirds of Ohio: cd guidebook [CDROM]. Columbus (OH): Ohio Department of Natural Resources, Division of Wildlife. Publication 418(306). 1 CD-ROM. OCLC No. 297224726.

https://legacylandandwildlife.com/wp-content/uploads/2017/11/ Waterbirds-of-Ohio-Ohio-Division-of-Wildlife.pdf

Ortega-Álvarez R, Lindig-Cisneros R. 2012. Feathering the scene: the effects of ecological restoration on birds and the role birds play in evaluating restoration outcomes. Ecol Restor. 30(2):116-127.

https://doi.org/10.3368/er.30.2.116

Peet RK, Wentworth TR, White PS. 1998. A flexible, multipurpose method for recording vegetation composition and structure. Castanea. 63(3):262-274. https://www.jstor.org/stable/4033979

Price EPF. 2016. Taxonomic homogenization of plant communities in Illinois wetlands and the role of wetland compensation [master's thesis]. [Urbana (IL)]: University of Illinois at Urbana-Champaign. http://hdl.handle.net/2142/95363 
Proulx G, Gilbert FF. 1983. The ecology of the muskrat, Ondatra zibethicus, at Luther Marsh, Ontario. Can Field Nat. 97(4):377-390.

https://www.biodiversitylibrary.org/page/28009082

R Core Team. 2018. R: a language and environment for statistical computing. Vienna (Austria): R Foundation for Statistical Computing. https://www.r-project.org/

Ratti JT, Rocklage AM, Giudice JH, Garton EO, Golner DP. 2001. Comparison of avian communities on restored and natural wetlands in North and South Dakota. J Wildlife Manage. 65(4):676-684.

https://doi.org/10.2307/3803019

Robertson M, Galatowitsch SM, Matthews JW. 2018. Longitudinal evaluation of vegetation richness and cover at wetland compensation sites: implications for regulatory monitoring under the Clean Water Act. Wetl Ecol Manag. 26(6):1089-1105. https://doi.org/10.1007/s11273-018-9633-8

Ruiz-Jaen MC, Aide TM. 2005. Restoration success: how is it being measured? Restor Ecol. 13(3):569-577. https://doi.org/10.1111/j.1526-100X.2005.00072.x

Seabloom EW, van der Valk AG. 2003. Plant diversity, composition, and invasion of restored and natural prairie pothole wetlands: implications for restoration. Wetlands. 23(1):1-12.

https://doi.org/10.1672/0277-5212(2003)023[0001:PDCAIO]2.0.CO;2

Sebastián-González E, Green AJ. 2014. Habitat use by waterbirds in relation to pond size, water depth, and isolation: lessons from a restoration in southern Spain. Restor Ecol. 22(3):311-318.

https://doi.org/10.1111/rec.12078

Seigel A, Hatfield C, Hartman JM. 2005. Avian response to restoration of urban tidal marshes in the Hackensack Meadowlands, New Jersey. Urban Habitats. 3(1):87-116. http://www.urbanhabitats.org/v03n01/

Spieles DJ, Coneybeer M, Horn J. 2006. Community structure and quality after 10 years in two central Ohio mitigation bank wetlands. Environ Manage. 38(5):837-852. https://doi.org/10.1007/s00267-005-0294-z

Svedarsky D, Grosshans R, Venema H, Ellis-Felege S, Bruggman J, Ostlund A, Lewis J. 2019. Integrated management of invasive cattails (Typha spp.) for wetland habitat and biofuel in the Northern Great Plains of the United States and Canada: a review. Mires Peat. 25:1-14. https://doi.org/10.19189/MaP.2018.APG.367
Tozer DC, Steele O, Gloutney M. 2018. Multispecies benefits of wetland conservation for marsh birds, frogs, and species at risk. J Environ Manage. 212:160-168. https://doi.org/10.1016/j.jenvman.2018.01.055

Tsipoura N, Burger J, Feltes R, Yacabucci J, Mizrahi D, Jeitner C, Gochfeld M. 2008. Metal concentrations in three species of passerine birds breeding in the Hackensack Meadowlands of New Jersey. Environ Res. 107(2):218-228. https://doi.org/10.1016/j.envres.2007.11.003

VanRees-Siewert KL, Dinsmore JJ. 1996. Influence of wetland age on bird use of restored wetlands in Iowa. Wetlands. 16(4):577-582.

https://doi.org/10.1007/BF03161348

Whigham DF. 1999. Ecological issues related to wetland preservation, restoration, creation and assessment. Sci Total Environ. 240(1-3):31-40. https://doi.org/10.1016/S0048-9697(99)00321-6

Williams JD, Dodd CK Jr. 1978. Importance of wetlands to endangered and threatened species. In: Greeson PE, Clark JR, Clark JE, editors. Wetland functions and values: the state of our understanding. Proceedings of the National Symposium on Wetlands. Minneapolis (MN): American Water Resources Association. p. 565-575. http://www.nativefishlab.net/library/textpdf/12005.pdf

Zedler JB. 2000. Progress in wetland restoration ecology. Trends Ecol Evol. 15(10):402-407. https://doi.org/10.1016/S0169-5347(00)01959-5

Zedler JB, Kercher S. 2004. Causes and consequences of invasive plants in wetlands: opportunities, opportunists, and outcomes. Crit Rev Plant Sci. 23(5):431-452. https://doi.org/10.1080/07352680490514673

Zedler JB, Kercher S. 2005. Wetland resources: status, trends, ecosystem services, and restorability. Annu Rev Env Resour. 30(1):39-74. https://doi.org/10.1146/annurev.energy.30.050504.144248

Zhang WW, Ma JZ. 2011. Waterbirds as bioindicators of wetland heavy metal pollution. Procedia Environ Sci. 10(c):2769-2774.

https://doi.org/10.1016/j.proenv.2011.09.429 